\title{
Effect of Applying Cold Plasma on Structural, Antibacterial and Self Cleaning Properties of $\alpha-\mathrm{Fe}_{2} \mathrm{O}_{3}$ (HEMATITE) Thin Film
}

\author{
Abdalhussain A. Khadayeir ${ }^{1^{*}}$, Ahmed H. Wannas ${ }^{1}$, Falah H. Yousif ${ }^{2}$ \\ ${ }^{1}$ Department of Physics, College Of Educations, University of Al-Qadisiyah, 58002, Iraq. \\ ${ }^{2}$ Educational Directorate of Diwaniyah, Al-Qadisiyyah, Iraq.
}

\begin{abstract}
Objective: In this study, $\alpha-\mathrm{Fe}_{2} \mathrm{O}_{3}$ thin film was formed on a glass substrate to study the impact of adding cold plasma on the self-cleaning and antibacterial properties of the samples. Method: The samples were synthesized using the chemical spray pyrolysis (CSP) method at $450^{\circ} \mathrm{C}$. X-ray powder diffraction (XRD), scanning electron microscope (FESEM), energy-dispersive X-ray spectroscopy (EDS), and atomic force microscope were used to investigate the morphological and structural characteristics of $\alpha-\mathrm{Fe}_{2} \mathrm{O}_{3}$ thin layers prior to and following plasma injection. Finding : The degree of wettability and antibacterial characteristics of iron oxide (hematite) thin film were evaluated in the presence of gram-negative and gram-positive bacteria prior to and following plasma injection, given the great potential of plasma injection in the surface modification of thin films. Novelty: The findings indicate that exposing plasma to $\alpha-\mathrm{Fe}_{2} \mathrm{O}_{3}$ thin film produces substantial changes in morphology, self-cleaning, and antibacterial characteristics.
\end{abstract}

\section{Keywords:}

Cold Plasma; $\alpha-\mathrm{Fe}_{2} \mathrm{O}_{3}$

Iron Oxide (Hematite);

Antibacterial;

Wettability.

\section{Article History:}

Received: 19 August 2021

Revised: $\quad 15 \quad$ November 2021

Accepted: $\quad 07$ December 2021

Published: 01 February 2022

\section{1- Introduction}

Plasma is a semi-neutral gas made up of charged and neutral particles that behave collectively [1, 2]. Plasma is classified into two main categories: high-temperature plasma (plasma fusion) and low-temperature plasma (gas discharge) or non-thermal plasma [3]. Non-thermal plasma is the state in which ions and neutral particles have the same temperature surrounding them, but the temperature of electrons is much higher. Most of the energy processed in the cold plasma turns into electrons in the plasma, thus making effective electrons rather than heating the gas in general. Ions and neutral particles are relatively cold. They have been used in the treatment of thermally sensitive materials, including polymers and biologics [4], various industrial and scientific applications [5], and tissue engineering [6]. The plasma has been generated by the barrier technique (DBD), which is usually used in the majority of industrial applications and technology. It is characterized by the other types of discharge that works for the production of non-thermal plasma at atmospheric pressure. This technique is used in the applications of surface treatment [7].

Metals have been used as antibacterial agents for many centuries [8-10]. With the development of nanotechnology, it was found that nanomaterials have a high tendency to interact with biological molecules and inactivate them [11, 12]. Among the various nanomaterials, iron oxide nanoparticles have unique properties, such as stability, low risk, and long durability, and are also resistant to a wide range of microbes [13-15]. Iron oxide nanoparticles have attracted special consideration over the last few years because of their wide range of applications in different industries, catalysts, and

* CONTACT: abdulhussain.khadyair@qu.edu.iq

DOI: http://dx.doi.org/10.28991/ESJ-2022-06-01-06

(C) 2022 by the authors. Licensee ESJ, Italy. This is an open access article under the terms and conditions of the Creative Commons Attribution (CC-BY) license (https://creativecommons.org/licenses/by/4.0/). 
biomedical fields such as drug delivery, antibody assessment, and thermotherapy [16-18]. Iron oxide nanostructures include magnetite nanoparticles $\left(\mathrm{Fe}_{3} \mathrm{O}_{4}\right)$, hematite nanoparticles $\left(\alpha-\mathrm{Fe}_{2} \mathrm{O}_{3}\right)$, and goethite micro-rods $(\alpha-\mathrm{FeOOH})$ [19]. Hematite is the most stable iron oxide phase, which has many applications in gas sensors, catalysts, and antibacterial materials [20]. The mechanism of the metal oxides effect on bacteria is not entirely clear, and researchers have suggested various mechanisms such as intervention in the electronic displacement of bacterium, intervention and destruction of bacterial DNA, interacting with the cell wall without entering into the cell, and formation of Histidine compounds and prevention of the respiration process. Because of this multiplicity of mechanisms, bacteria cannot adapt to or resist the metal oxides [21].

Plasma techniques have long been used to make new materials with unique properties. A very important technique that has many advantages is plasma deposition for producing completely new materials with unusual molecular structures and complex Nano-morphology [22, 23]. Plasma processes can also be used to modify the surface of usual materials by treating them during the manufacturing process or after synthesis, generally leading to the production of new materials with different properties, which are often more suitable than non-modified materials. The research findings show that huge potential lies in cold plasma technology. This technology gives us almost unlimited power to modify various materials and produce completely new structures. Given the importance and attractiveness of this topic in the article, we decided to examine the effect of plasma injection on the structural, morphology, antibacterial and selfcleaning properties of iron oxide (hematite) thin films. Iron oxide thin film was characterized prior to and following plasma injection via X-ray powder diffraction spectroscopy, FESEM microscope, atomic force microscope, and EDX analysis. Microorganisms are part of the organic materials which can affect human life and have caused a lot of difficulties for humans. Due to the growth of microbial problems, the main purpose of this research is the study of antibacterial properties of hematite thin films after using plasma treatment on their surfaces.

\section{2- Experimental Methods}

Solution Preparation: $4.055 \mathrm{~g} \mathrm{FeCl}_{3}$ was added to $250 \mathrm{ml}$ doubly distilled water to make the hematite $\mathrm{Fe}_{2} \mathrm{O}_{3}$ solution.

Thin Film Preparation: On warmed glass substrates, the transparent yellow solution was sprayed. A pneumatic nebulizer with a $0.7 \mathrm{~mm}$ nozzle diameter was used to deliver this solution. The spraying procedure took approximately 15 seconds. The time between spraying operations was approximately 3 minutes; this was adequate to keep the glass substrates from overheating. During the deposition process, the solution molarity, spraying nozzle height and spray process rate are all maintained constant at $0.1 \mathrm{M}, 30 \mathrm{~cm}$ and $10 \mathrm{~cm}^{3} / \mathrm{min}$, respectively, to achieve homogeneous thin layers. The color of thin films that were produced ranged from reddish brown to black. The substrate temperature was measured using a temperature controller, and the resistance heater was controlled by a thermocouple. The thin layers were deposited by spraying the solution onto heated glass substrates. The substrate temperature was set at $450^{\circ} \mathrm{C}$.

Plasma Treatment: The following settings were used to conduct plasma treatment on $\mathrm{Fe}_{2} \mathrm{O}_{3}$ layers. Plasma injection activates the surface of iron oxide thin films, and causes roughness on the surface. So the surface is prepare for subsequent procedures. A space of approximately $4 \mathrm{~cm}$ between the plasma head and the thin sheet was chosen. The thin film treatment parameters are shown in Table 1.

Coating Antibacterial Solution: At this stage, the desired solution coating started on the surface completely uniformly. Plasma surface pre-treatment in the previous stage results in finer adhesion and absorption of the solution in this step. The coating of the samples was done by a 200 ppm nano-silver antibacterial solution.

Drying: At this stage, iron oxide thin films entered the dryer and were heated and dried. It was the radiant dryer and the temperature of the sample was $200^{\circ} \mathrm{C}$. The flow chart of research methodology is shown in figure 1.

Table 1. Treatment Parameters of $\mathrm{Fe}_{2} \mathrm{O}_{3}$ Thin Film by Cold Plasma Device

\begin{tabular}{cc}
\hline Input Voltage & $220 \mathrm{v}, 50 \mathrm{~Hz}$ \\
Output Voltage & $10 \mathrm{kv}$ \\
Operation (Working) Frequency & $20 \mathrm{kHz}$ \\
Power & $1 \mathrm{~kW}$ \\
Consumption Gas & Air \\
Spray Nozzle Type & Automatic Spray un \\
Temperature Range of Dryer & $200^{\circ} \mathrm{C}$ \\
\hline
\end{tabular}

Characterization: An X-ray powder diffraction spectroscopy (XRD) equipment, D8 Advance Bruker YT type, was utilized to validate the structure of the produced iron oxide layers, by CuK radiation at $=1.5418 \mathrm{~A}$ ranging from 5 to 80 . A FESEM microscope, MIRA3 TESCAN-XMU type implemented by EDX probe, was utilized to examine the surface morphology and chemical analysis of the produced layers. Atomic force microscope pictures taken from an AFM 
equipment made by Ara-Research Company were utilized to examine the surface topology of the layers. The water droplets with 1 micro liter volume was placed on iron oxide thin film in ambient temperature to investigate the contact angle by an AM-7013MZT from Dino-Lite, Taiwan, to determine the samples' self-cleaning capabilities. Water droplets were put in three distinct locations for one sample, and the contact angle was calculated using the average of these positions. Escherichia coli DH5 alpha (as Gram-negative bacteria) and S. aureus (as gram-positive bacteria) were used to test antibacterial capabilities.

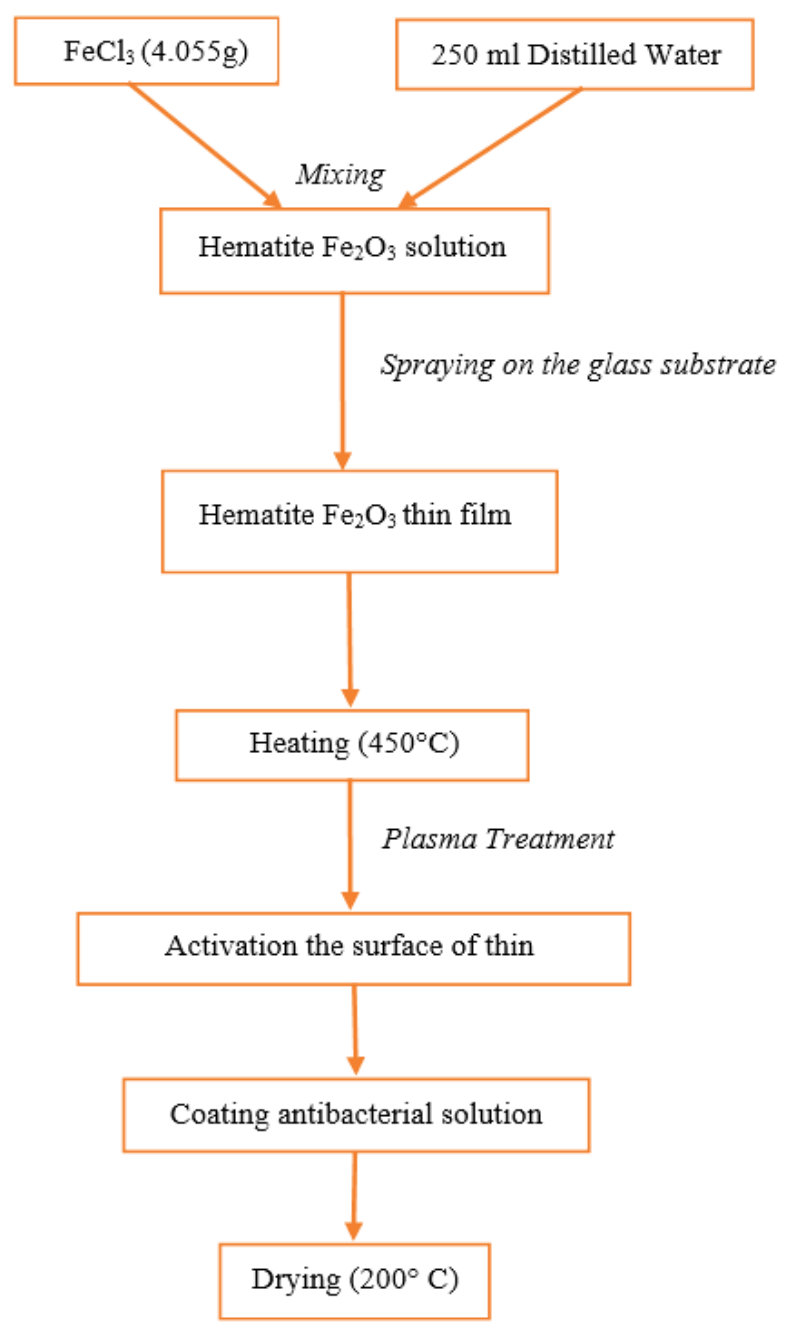

Figure 1. Flow chart of research methodology

\section{3- Results and Discussion}

\section{3-1- XRD Analysis}

The crystalline structure of $\mathrm{Fe}_{2} \mathrm{O}_{3}$ thin films was studied and analyzed prior to and following the application of plasma by X-ray diffraction using $\mathrm{CuK}_{\alpha}$ radiation $\left(1.5406 \AA\right.$ ). The angle $2 \theta$ was selected from $5^{\circ}$ to $80^{\circ}$ with a step of 0.05. Figure 2 shows the X-ray diffraction pattern of $\mathrm{Fe}_{2} \mathrm{O}_{3}$ thin films prior to and following the plasma application. According to the Figure, $\alpha-\mathrm{Fe}_{2} \mathrm{O}_{3}$ (hematite) phase is completely formed, which related to the standard card NO. 330664, the results reported by the researchers [24-29], and similar reported results for $\alpha-\mathrm{Fe}_{2} \mathrm{O}_{3}$ thin layers. From XRD images, it is clear that prepared $\alpha-\mathrm{Fe}_{2} \mathrm{O}_{3}$ thin layers are arranged along (104) plane. Tadic et al. reported the preparation of hematite $\left(\alpha-\mathrm{Fe}_{2} \mathrm{O}_{3}\right)$ nanoparticles by hydrothermal synthesis procedure. XRD results show that the positions of all peaks are characteristic of the $\alpha-\mathrm{Fe}_{2} \mathrm{O}_{3}$ phase in accordance with JCPDS card 33-0664. No diffraction peak relating to other phases has been observed, showing that it is composed of the pure phase of $\alpha-\mathrm{Fe}_{2} \mathrm{O}_{3}$ [26]. There are no peaks correspond to other phases or impurity, showing the high purity of the synthesized films. The peaks are located at the angles of $24.22^{\circ}, 33.22^{\circ}, 35.67^{\circ}, 40.90^{\circ}, 49.53^{\circ}, 54.13^{\circ}, 57.61^{\circ}, 62.25^{\circ}$, and $72.09^{\circ}$, relating to the plates of $(012),(104)$, (110), (113), (024), (116), (122), (214), and (1010), respectively. These peaks show the formation of hexagonal $\alpha-\mathrm{Fe}_{2} \mathrm{O}_{3}$ structure with R3 ${ }^{-} \mathrm{c}$ (No.167) space group. After plasma surface treatment, the structure of $\mathrm{Fe}_{2} \mathrm{O}_{3}-\mathrm{P}$ film did not change compared to $\mathrm{Fe}_{2} \mathrm{O}_{3}$ thin film, and only a small shift is seen at the location of the peaks, meaning that the lattice parameters were reduced. This can be related to the structural relaxation and the elimination of defects after applying the plasma [30]. 


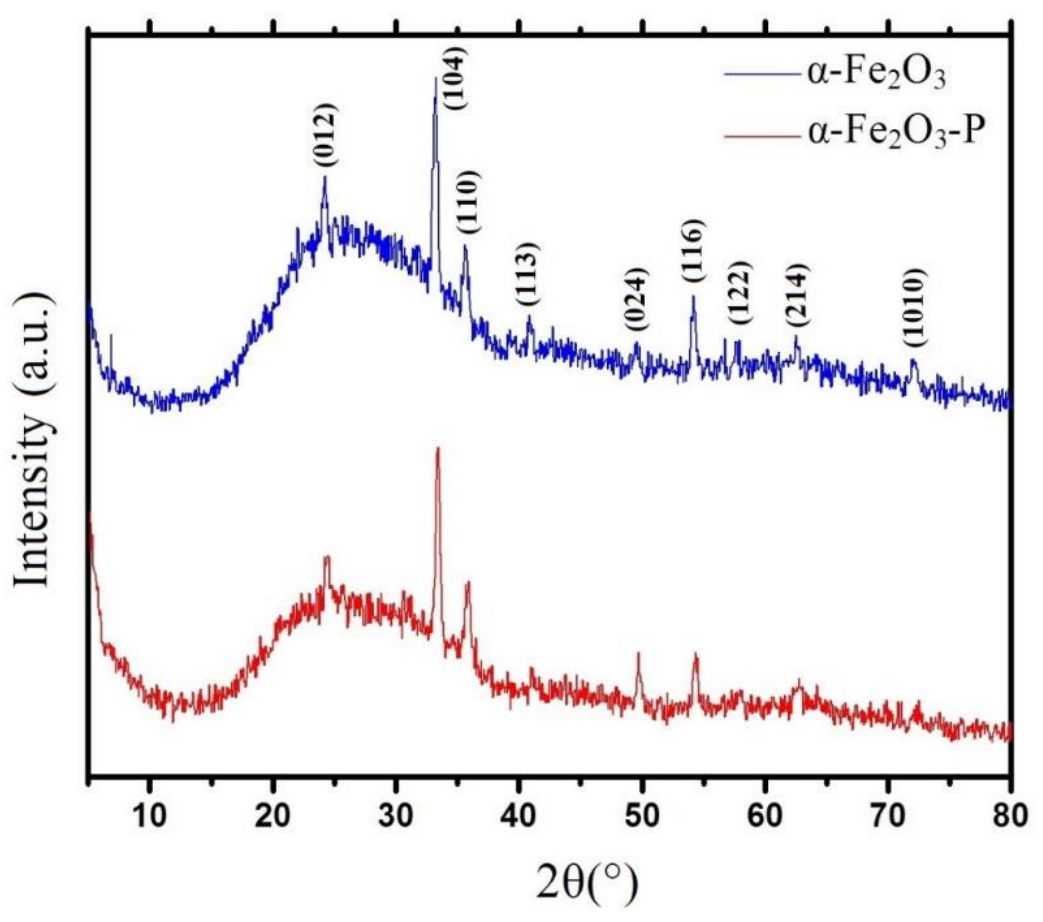

Figure 2. X-ray Powder Diffraction Pattern of $\alpha-\mathrm{Fe}_{2} \mathrm{O}_{3}$ Thin Films prior to the Plasma application and $\alpha-\mathrm{Fe}_{2} \mathrm{O}_{3}-\mathrm{P}$ following the Plasma application

\section{3-2- FESEM Microscope}

FESEM microscope and EDS images were utilized to investigate the particle size distribution, morphological aspects and chemical composition of iron oxide (hematite) thin layers prior to and following plasma injection. FESEM image of $\alpha-\mathrm{Fe}_{2} \mathrm{O}_{3}$ thin film prior to the plasma application is shown in Figure 3a and its lateral cross-section in Figure $3 b$.

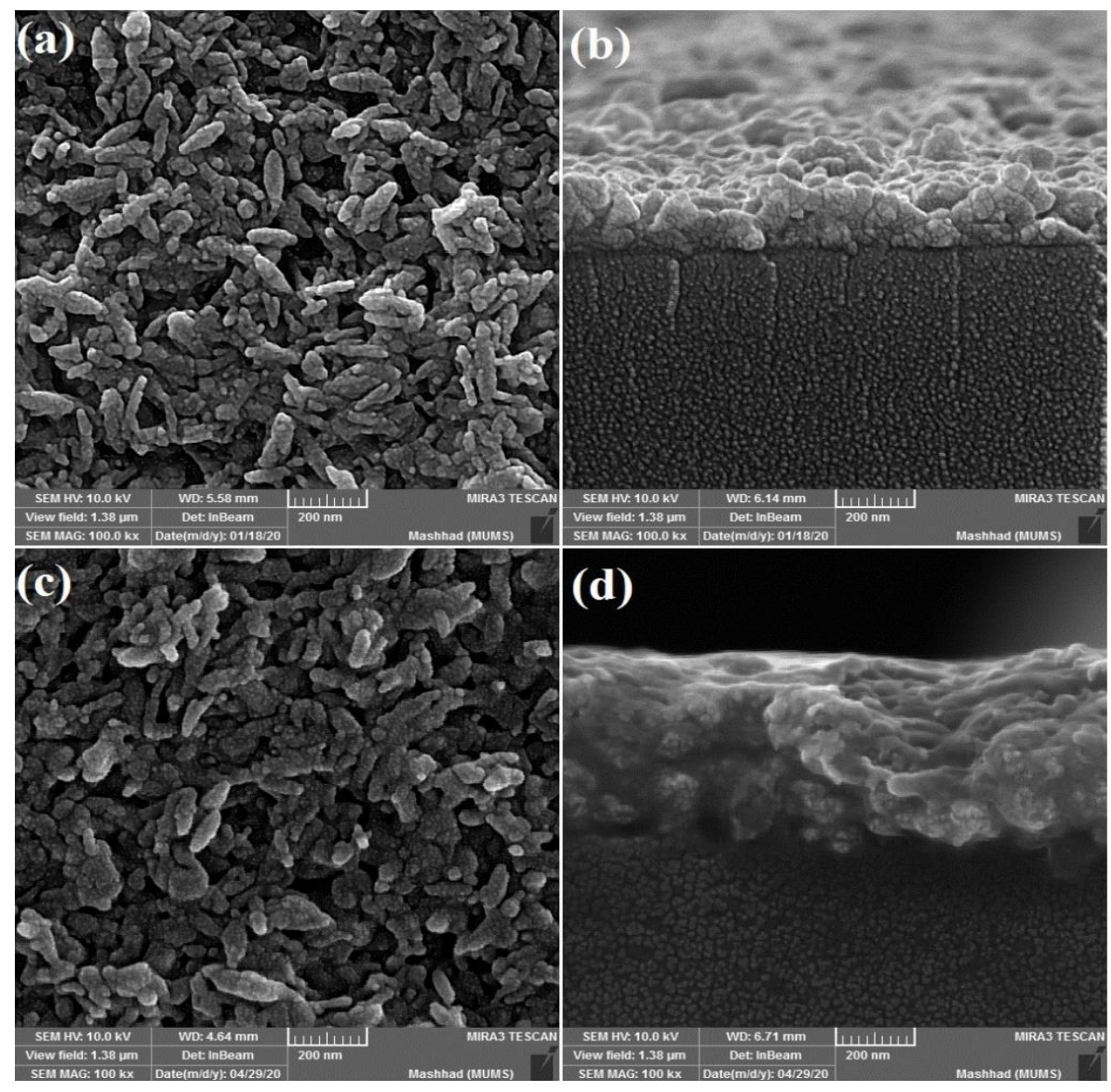

Figure 3. Field-Effect Scanning Electron Microscope Image of $\alpha-\mathrm{Fe}_{2} \mathrm{O}_{3}$ Thin Films, (a, b) prior to the plasma application and $(c, d)$ following the plasma application. Figures $b, d$ show the cross-section area of the films 
According to the Figure, iron oxide nanoparticles have needle-like structures that are formed by agglomeration and accumulation of smaller particles [31-32]. Kouotou et al. deposited $\alpha-\mathrm{Fe}_{2} \mathrm{O}_{3}$ thin layers by pulsed spray evaporation chemical vapor technique and studied the effect of the deposition temperature. According to their SEM results, the film structure synthesized at $350^{\circ} \mathrm{C}$ was composed of small grains. At $400^{\circ} \mathrm{C}$, the film showed a uniform densely packed structure with octahedral grains. At $450^{\circ} \mathrm{C}$, the samples presented needle-like structures, each of which could result from the agglomeration and incorporation of small individual particles [32]. This morphology is similar to our result that our samples were prepared at $450^{\circ} \mathrm{C}$ and had needle-like structures. The average length of these needle structures is above $100 \mathrm{~nm}$ and their diameter is less than $50 \mathrm{~nm}$. According to the cross-section image, the film thickness is also less than $100 \mathrm{~nm}$. FESEM image of the $\alpha-\mathrm{Fe}_{2} \mathrm{O}_{3}-\mathrm{P}$ thin film after the plasma injection is shown in Figure $3 \mathrm{c}$ and its lateral crosssection in Figure 3d. After plasma injection, it appears that these needle-like structures are attached and bonded together, eventually increasing the particle size. The agglomeration of the structure is seen and confirmed in the images of the lateral cross-section of the sample and AFM image. After applying the plasma, the film thickness is more than $200 \mathrm{~nm}$.

The chemical composition of $\alpha-\mathrm{Fe}_{2} \mathrm{O}_{3}$ film was investigated prior to and following plasma treatment, using the EDX spectroscopy and the results are presented in Figure 4. The presence of $\mathrm{O}$ and Fe elements and the nonexistence of other elements confirm the growth of pure iron oxide layer [33]. The weight ratio of the oxygen and iron elements in the samples is also reported in Figure 4. As shown in the Figure, applying the plasma increases the weight ratio of the oxygen atom and decreases the weight ratio of the iron atom.

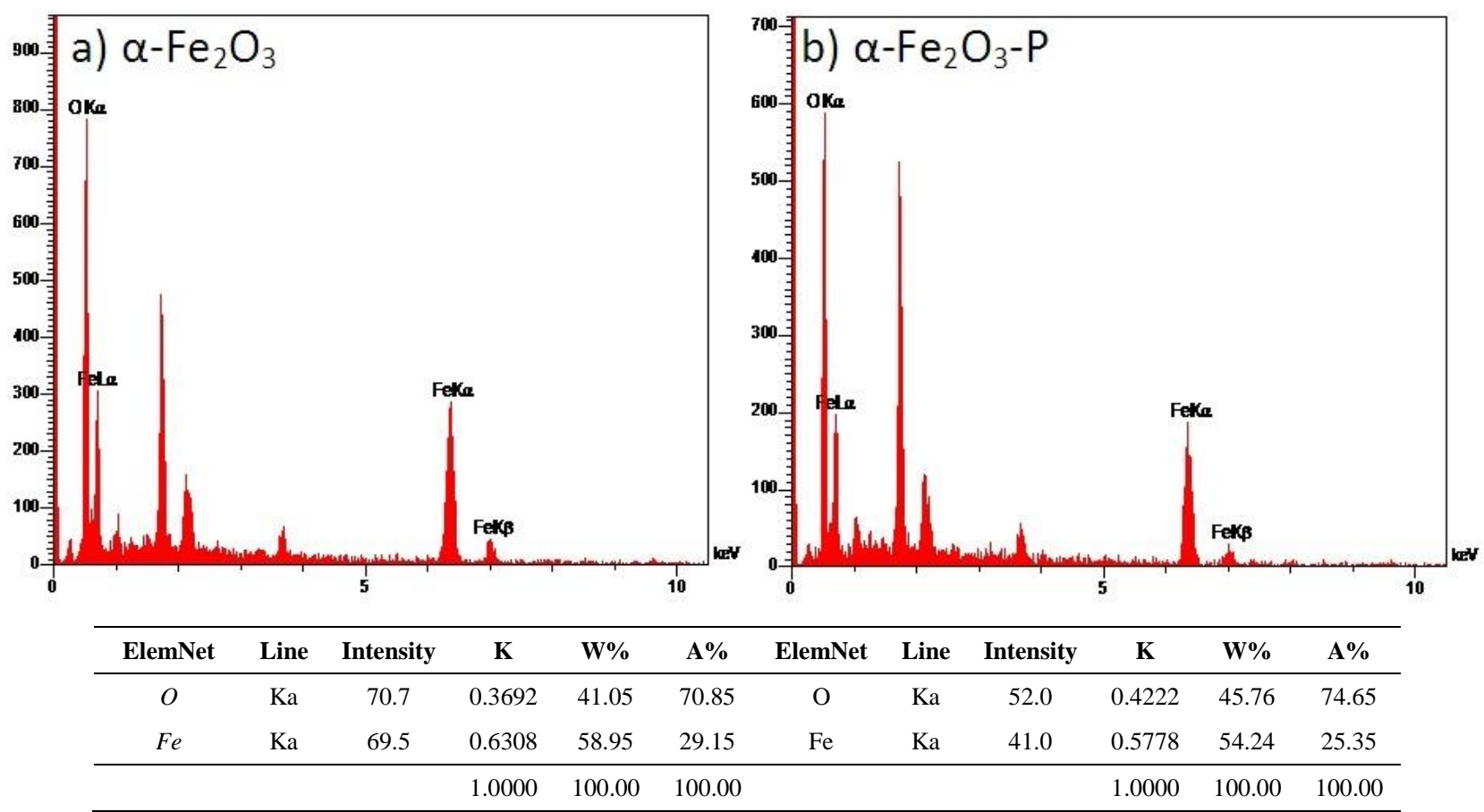

Figure 4. EDX Image of $\alpha-\mathrm{Fe}_{2} \mathrm{O}_{3}$ Thin Films, (a) prior to the plasma application and (b) following the plasma application

\section{3-3- AFM Microscope}

The images of atomic force microscope (AFM) were used to study the surface morphology of $\alpha-\mathrm{Fe}_{2} \mathrm{O}_{3}$ thin films formed prior to and following plasma treatment. According to the AFM (2D) photograph of $\alpha-\mathrm{Fe}_{2} \mathrm{O}_{3}$ layer shown in Figure 5 (a), the morphology is uniform. The root mean square (RMS) of the roughness level is also measured by AFM image and shown in Figure 5b, which is $94.51 \mathrm{~nm}$. Figure 5c exhibits the AFM (2D) photograph of $\alpha-\mathrm{Fe}_{2} \mathrm{O}_{3}$ layer after plasma treatment. By analyzing the AFM (3D) images after plasma treatment shown in Figure 5d, surface roughness was evaluated as RMS parameter. There is a significant difference between the morphology of the films prior to and following plasma treatment. While the synthesized thin films led to dense compressed small grains and eventually to a smooth surface, after treatment using the plasma jet method, the films consist of much larger grains (nanopyramidal pattern) and seemingly higher porosity. This enhancement of grain size is the result of radiation pressure from photons, ions, and atoms bombardment by plasma activation. On the other hand, higher porosity may be desirable for anticipated photo-electrochemical applications. This is a well-known phenomenon that by increasing the surface area because of porosity, light scattering and penetration increases. Additionally, the inverse recombination of electron-hole pairs is prevented by larger grains [34]. For this film, roughness (RMS) of $65.15 \mathrm{~nm}$ was obtained. 


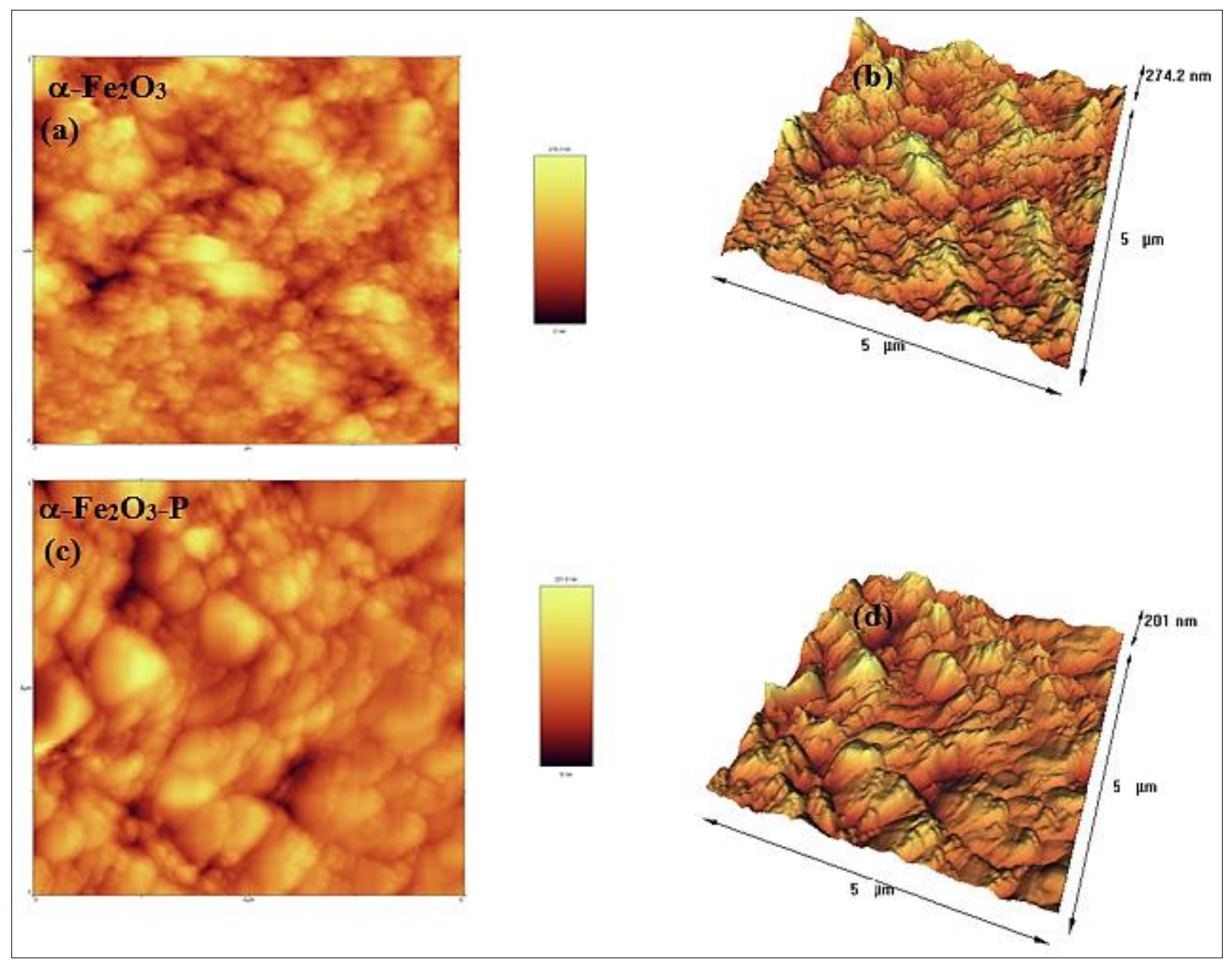

Figure 5. Surface Properties of $\alpha-\mathrm{Fe}_{2} \mathrm{O}_{3}$ Films (a) Prior to Plasma Treatment (2D), (b) Prior to Plasma Treatment (3D), (c) Following Plasma Treatment (2D), (d) Following Plasma Treatment (3D)

\section{3-4- Wettability (Contact Angle)}

The solid wetting by water depends on the relationship between surface stresses (solid/water, air/water, and air/solid). Surface wettability can be described by contact angle (CA). Surface wetting happens when CA is $<90^{\circ}$ and non-wetting happens when contact angle is $>90^{\circ}$. Therefore, they are named hydrophile and hydrophobe, respectively [35-36]. The mean contact angle was specified by calculating several separate droplets of distilled water on each surface of $\alpha-\mathrm{Fe}_{2} \mathrm{O}_{3}$ thin film synthesized prior to and following plasma treatment. The contact angle measured by the water of $\alpha-\mathrm{Fe}_{2} \mathrm{O}_{3}$ thin films before plasma treatment is shown in Figure $6 \mathrm{a}$ and $\alpha-\mathrm{Fe}_{2} \mathrm{O}_{3}-\mathrm{P}$ after plasma treatment in Figure $6 \mathrm{~b}$.
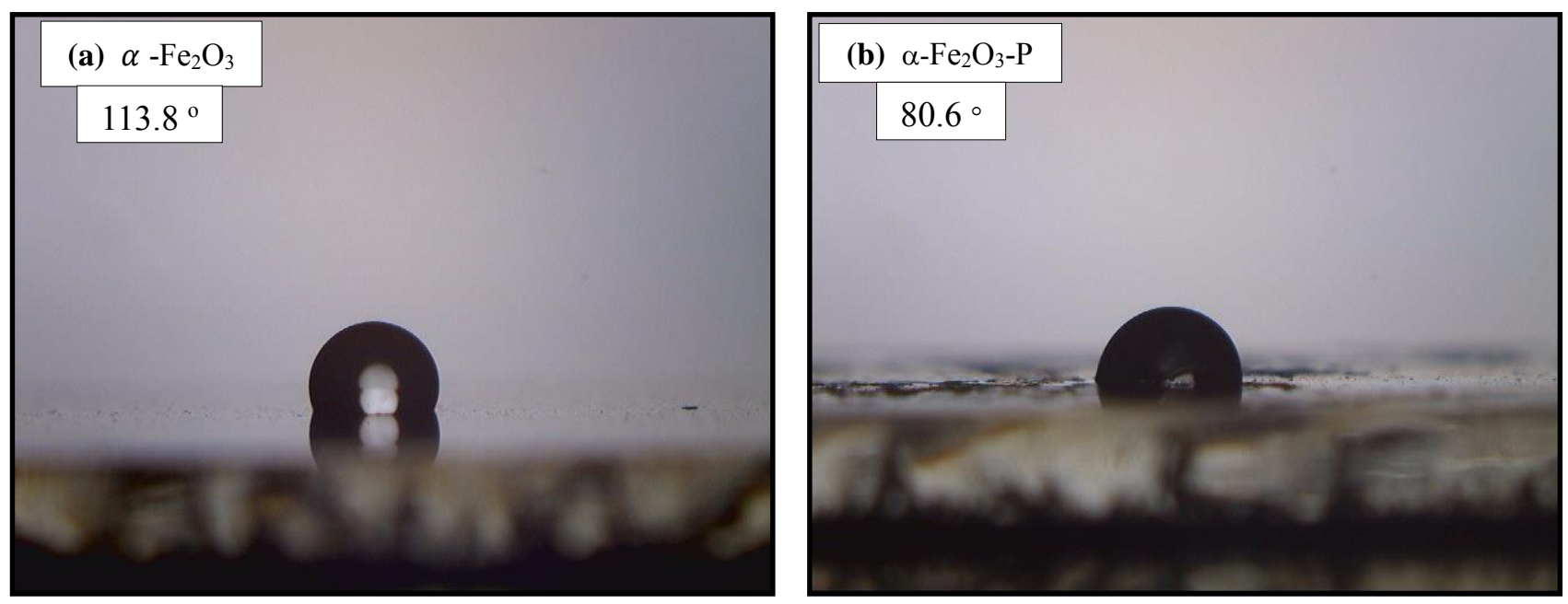

Figure 6. The Contact Angle Measured between the Surface of $\alpha-\mathrm{Fe}_{2} \mathrm{O}_{3}$ Thin Film and the Water Droplet (a) prior to Plasma Treatment and (b) following Plasma Treatment $\left(\alpha-\mathrm{Fe}_{2} \mathrm{O}_{3}-\mathrm{P}\right)$ 
In the thin film prior to plasma treatment, with 113.8 contact angle, hydrophobic behavior is observed and for the thin film following plasma treatment with the contact angle of 80.6, hydrophilic behavior is seen. The low contact angle $\left(\alpha-\mathrm{Fe}_{2} \mathrm{O}_{3}-\mathrm{P}\right.$ after plasma treatment sample) is due to the great cohesive force between the water droplets and the (-OH) group present on the $\alpha-\mathrm{Fe}_{2} \mathrm{O}_{3}$ film. By plasma treatment, the surface roughness is reduced and the behavior of the films shows hydrophilicity. Plasma treatment is an advanced technique that can make wetting a surface straightforward and promising by providing different types of surface functional groups and rough structures. By $\mathrm{O}_{2}$ plasma, superhydrophilic surfaces can be effortlessly obtained.

Surface wetting of the film is mainly influenced by the morphology of the surface and confirms the FESEM and AFM images. The dense microstructure of the film surface shows a greater water contact angle. The reason for this behavior is that the gas bubbles with high roughness are embedded between the water droplet and the insulation surface [37-38].

\section{3-5- Antibacterial Activity}

Prior to and following plasma injection, the antibacterial characteristics of the produced $\alpha-\mathrm{Fe}_{2} \mathrm{O}_{3}$ layers were examined. Figures 7 and 8 show the results of studies on E. coli and S. aureus bacteria cultured for 1 day on an empty glass substrate and $\alpha-\mathrm{Fe}_{2} \mathrm{O}_{3}$ layer surfaces incubated prior to and following plasma injection. The diffusion of metal ions is a crucial component in the antibacterial activities of metal oxide nanoparticles [39], which is a well-known issue. When iron ions are put in $\mathrm{Fe} 3+$ forms in $-\mathrm{Fe}_{2} \mathrm{O}_{3}$, they are reduced and transformed to $\mathrm{Fe} 2+$ by generating the free hydroxyl radical when they come into contact with an aqueous solution containing bacteria [40]. Free hydroxyl radicals and $\mathrm{Fe} 2+$ ions are both extremely reactive, causing damage to proteins and nucleic acids, disrupting DNA replication, and killing S. aureus bacterium. Also, when a bacterial cell come in contact with these nanoparticles, active oxygen is make caused by the chemisorption procedure. Thus, more iron and hydroxide ions or hydrogen peroxide are released from the surface, which can react with the peptide linkages in the bacterial cell wall and disrupt them. This antibacterial mechanism may be involved in the antibacterial study to kill the S. aureus microorganisms. It is proven that plasma jet therapy inhibits germs from growing on hard surfaces and in liquid settings [41-53]. As a result, researchers are looking into the effects of plasma jet therapy on both gram negative and gram positive bacteria.

As depicted in Figure 7, for Staphylococcus bacteria in $\alpha-\mathrm{Fe}_{2} \mathrm{O}_{3}$ film, the growth of the bacterium was showed by $10 \%$ prior to plasma injection in comparison to the control sample. While following plasma injection, there was a significant fall, and inhibition by $99 \%$ in the bacterial growth compared to the control sample. In Figure 8, the $\alpha-\mathrm{Fe}_{2} \mathrm{O}_{3}$ film was able to inhibit the growth of E. coli bacteria by $10 \%$ prior to plasma treatment in comparison to the control sample, which this rate reached $99 \%$ after exposure to plasma jet and drying at $200^{\circ} \mathrm{C}$ compared to the control sample. It is clear that plasma jet treatment under certain current and voltage conditions and appropriate drying temperature has a considerable effect on inhibiting the growth of gram-negative and gram-positive bacteria. Shin et al. prepared the iron oxide nanoparticles using the sonochemical method and analyzed their bioactivities by the disk diffusion method. The nanoparticles presented the inhibitory effect on bacterial pathogens against B. cereus, S. aureus, E. coli and S. enterica [54]. Belkhedkar et al. investigated the antibacterial activity of Mn-doped $\mathrm{Fe}_{2} \mathrm{O}_{3}$ thin films synthesized using ionic layer adsorption and reaction method. The antibacterial activity of the $\alpha-\mathrm{Fe}_{2} \mathrm{O}_{3}$ layers was studied against $\mathrm{S}$. aureus bacteria. Their results showed that the antibacterial efficiency for the pure hematite film is $16.66 \%$ which is in agreement with the results of this study [55].

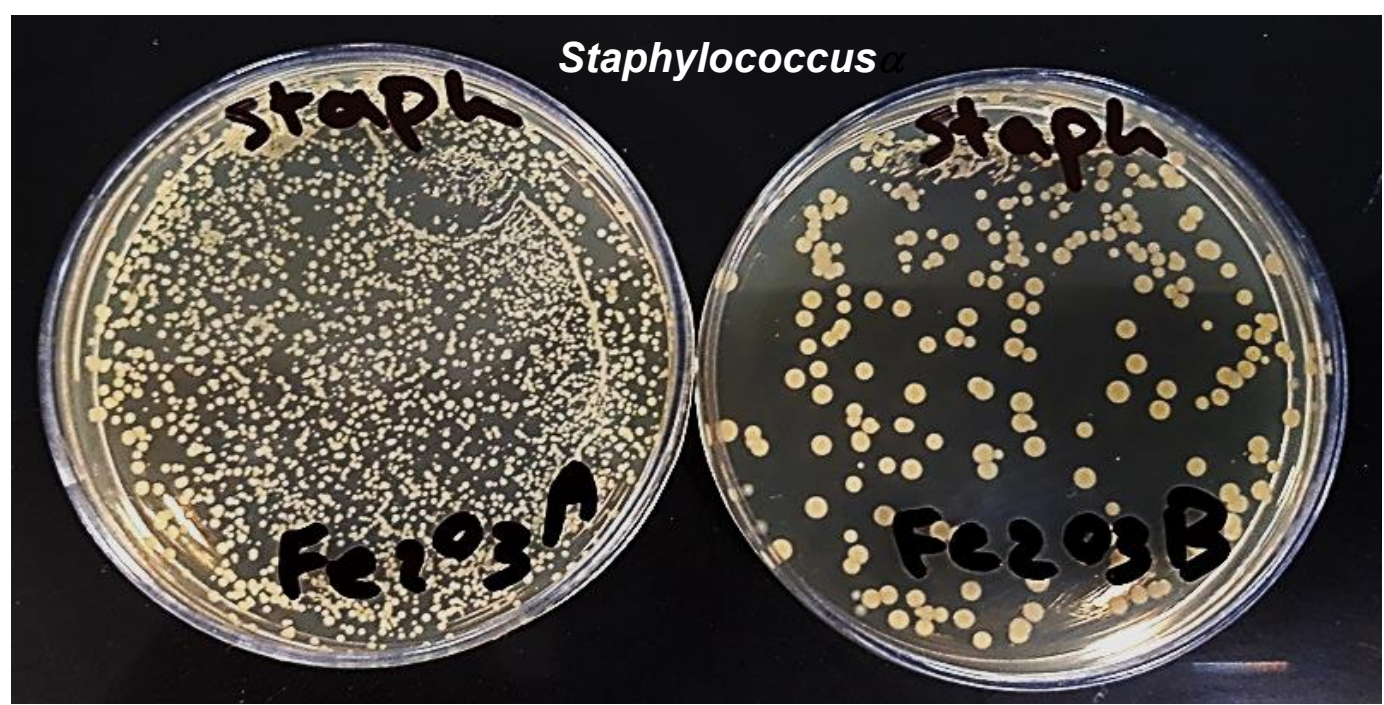

Figure 7. Antibacterial Activity on Staphylococcus Bacterium in (a) $\alpha-\mathrm{Fe}_{2} \mathrm{O}_{3}$ prior to Plasma Injection and (b) $\alpha-\mathrm{Fe}_{2} \mathrm{O}_{3}-\mathrm{P}$ following Plasma Injection 


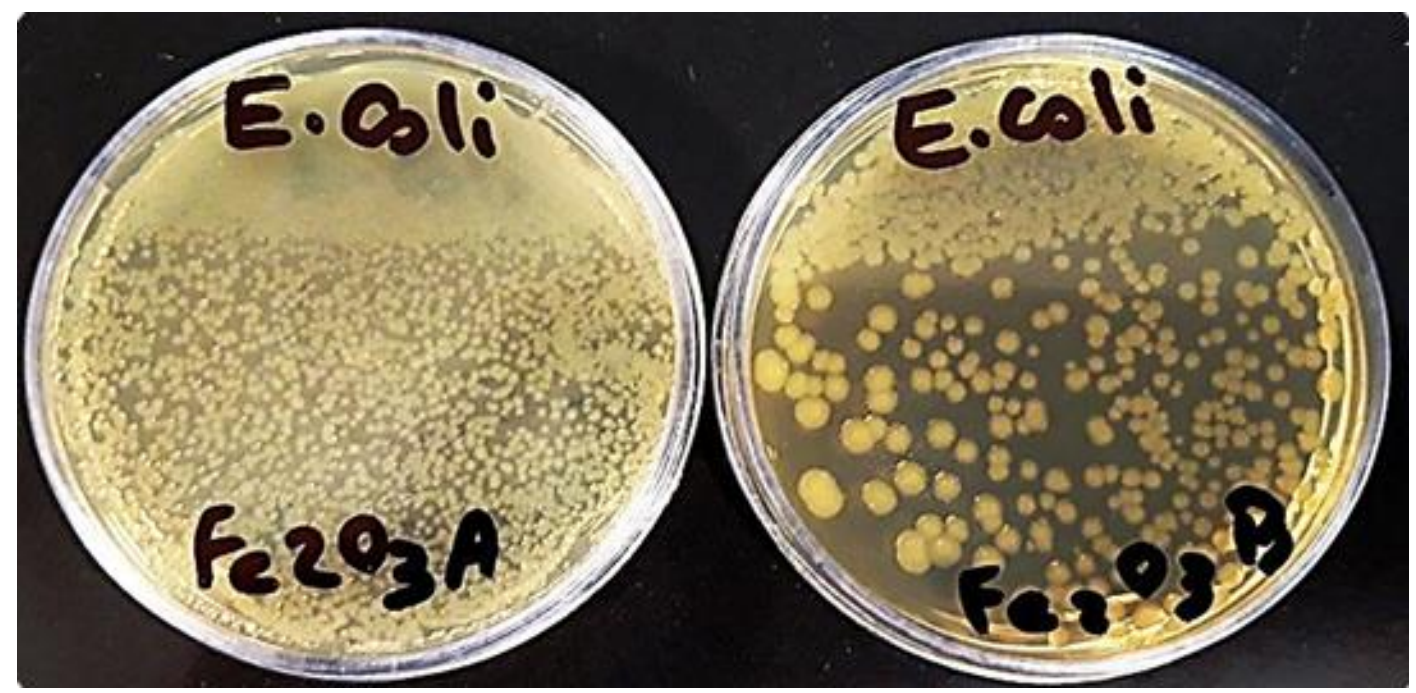

Figure 8. Antibacterial Activity on E. coli Bacterium in the Film (a) $\alpha-\mathrm{Fe}_{2} \mathrm{O}_{3}$ prior to Plasma Injection and (b) $\alpha-\mathrm{Fe}_{2} \mathrm{O}_{3}-\mathrm{P}$ following Plasma Injection

\section{4- Conclusion}

In this research, $\alpha-\mathrm{Fe}_{2} \mathrm{O}_{3}$ thin film was synthesized and deposited by the chemical spray pyrolysis (CSP) technique. The surface of $\alpha-\mathrm{Fe}_{2} \mathrm{O}_{3}$ thin film was treated with cold plasma with $1 \mathrm{~kW}$ power while air was present and the temperature was $200{ }^{\circ} \mathrm{C}$, and the samples were analyzed prior to and following the application of plasma. The development of the hematite phase was completely confirmed by inspecting the X-ray diffraction spectrum. The XRD spectra did not alter much prior to and following plasma application. There was no impurity phase in the samples, according to XRD and EDX findings. FESEM and AFM microscopes were used to examine the surface morphology of the layers. The findings indicated that following plasma treatment, the particles were linked and agglomerated together. The contact angle between the samples surface and the water droplet was reduced following plasma injection, according to research. In fact, plasma treatment decreased surface roughness and resulted in a hydrophilic $\alpha-\mathrm{Fe}_{2} \mathrm{O}_{3}$ thin layer. When studying the antimicrobial activities of $\alpha-\mathrm{Fe}_{2} \mathrm{O}_{3}$ thin film against E. coli and Staphylococcus bacteria, it was discovered that prior to plasma injection, bacterial growth was inhibited by $10 \%$, while after plasma injection, bacterial growth was inhibited by 99 percent, and $\alpha-\mathrm{Fe}_{2} \mathrm{O}_{3}$ thin film was able to inhibit bacterial growth by 99 percent.

\section{5- Declarations}

\section{5-1-Author Contributions}

A.A.K., A.H.W., and F.H.Y. contributed to the design and implementation of the research, to the analysis of the results and to the writing of the manuscript. All authors have read and agreed to the published version of the manuscript.

\section{5-2-Data Availability Statement}

The data presented in this study are available in article.

\section{5-3- Funding}

This work was supported by University of Al-Qadisiyah.

\section{5-4- Conflicts of Interest}

The authors declare that there is no conflict of interests regarding the publication of this manuscript. In addition, the ethical issues, including plagiarism, informed consent, misconduct, data fabrication and/or falsification, double publication and/or submission, and redundancies have been completely observed by the authors.

\section{6- References}

[1] Nehra, V., Kumar, A., \& Dwivedi, H. K. (2008). Atmospheric non-thermal plasma sources. International Journal of Engineering, 2(1), 53-68.

[2] Júnior, J. W. N., Monção, R. M., Bandeira, R. M., Ribeiro dos Santos Júnior, J., Araujo, J. F. D. F., Moura, J. V. B., Lima, L. B. S., Santos, F. E. P., Lima, C. da L., Costa, T. H. de C., \& de Sousa, R. R. M. (2021). Growth of $\alpha$-Fe2O3 thin films by plasma deposition: Studies of structural, morphological, electrochemical, and thermal-optical properties. Thin Solid Films, 736, 138919. doi:10.1016/j.tsf.2021.138919. 
[3] Ramachandran, R. K., Dendooven, J., \& Detavernier, C. (2014). Plasma enhanced atomic layer deposition of Fe2O3 thin films. Journal of Materials Chemistry A, 2(27), 10662-10667. doi:10.1039/c4ta01486c.

[4] Lee, E. T., Jang, G. E., Kim, C. K., \& Yoon, D. H. (2001). Fabrication and gas sensing properties of $\alpha$-Fe2O3 thin film prepared by plasma enhanced chemical vapor deposition (PECVD). Sensors and Actuators, B: Chemical, 77(1-2), 221-227. doi:10.1016/S0925-4005(01)00716-X.

[5] Herrmann, H. W., Henins, I., Park, J., \& Selwyn, G. S. (1999). Decontamination of chemical and biological warfare (CBW) agents using an atmospheric pressure plasma jet (APPJ). Physics of Plasmas, 6(5 I), 2284-2289. doi:10.1063/1.873480.

[6] Pirovano, C., Islam, M. S., Vannier, R. N., Nowogrocki, G., \& Mairesse, G. (2001). Modelling the crystal structures of Aurivillius phases. Solid State Ionics, 140(1-2), 115-123. doi:10.1016/S0167-2738(01)00699-3.

[7] Liu, G., Tuttle, B. R., \& Dhar, S. (2015). Silicon carbide: A unique platform for metal-oxide-semiconductor physics. Applied Physics Reviews, 2(2), 21307. doi:10.1063/1.4922748.

[8] Wan, Y. Z., Raman, S., He, F., \& Huang, Y. (2007). Surface modification of medical metals by ion implantation of silver and copper. Vacuum, 81(9), 1114-1118. doi:10.1016/j.vacuum.2006.12.011.

[9] Matyar, F., Kaya, A., \& Dinçer, S. (2008). Antibacterial agents and heavy metal resistance in Gram-negative bacteria isolated from seawater, shrimp and sediment in Iskenderun Bay, Turkey. Science of the Total Environment, 407(1), 279-285. doi:10.1016/j.scitotenv.2008.08.014.

[10] Yasuyuki, M., Kunihiro, K., Kurissery, S., Kanavillil, N., Sato, Y., \& Kikuchi, Y. (2010). Antibacterial properties of nine pure metals: A laboratory study using Staphylococcus aureus and Escherichia coli. Biofouling, 26(7), 851-858. doi:10.1080/08927014.2010.527000.

[11] Bhatt, I., \& Tripathi, B. N. (2011). Interaction of engineered nanoparticles with various components of the environment and possible strategies for their risk assessment. Chemosphere, 82(3), 308-317. doi:10.1016/j.chemosphere.2010.10.011.

[12] Saptarshi, S. R., Duschl, A., \& Lopata, A. L. (2013). Interaction of nanoparticles with proteins: Relation to bio-reactivity of the nanoparticle. Journal of Nanobiotechnology, 11(1), 1-12. doi:10.1186/1477-3155-11-26.

[13] Ramimoghadam, D., Bagheri, S., \& Hamid, S. B. A. (2014). Progress in electrochemical synthesis of magnetic iron oxide nanoparticles. Journal of Magnetism and Magnetic Materials, 368, 207-229. doi:10.1016/j.jmmm.2014.05.015.

[14] Neyaz, N., Siddiqui, W. A., \& Nair, K. K. (2014). Application of surface functionalized iron oxide nanomaterials as a nanosorbents in extraction of toxic heavy metals from ground water : A review. International Journal of Environmental Sciences, 4(4), 472-483. doi:10.6088/ijes.2014040400004.

[15] Lu, Y., Yin, Y., Mayers, B. T., \& Xia, Y. (2002). Modifying the Surface Properties of Superparamagnetic Iron Oxide Nanoparticles through a Sol-Gel Approach. Nano Letters, 2(3), 183-186. doi:10.1021/n1015681q.

[16] Wang, Y.-X., Xuan, S., Port, M., \& Idee, J.-M. (2013). Recent Advances in Superparamagnetic Iron Oxide Nanoparticles for Cellular Imaging and Targeted Therapy Research. Current Pharmaceutical Design, 19(37), 6575-6593. doi:10.2174/1381612811319370003.

[17] Kagan, D., Laocharoensuk, R., Zimmerman, M., Clawson, C., Balasubramanian, S., Kang, D., Bishop, D., Sattayasamitsathit, S., Zhang, L., \& Wang, J. (2010). Rapid delivery of drug carriers propelled and navigated by catalytic nanoshuttles. Small, 6(23), 2741-2747. doi:10.1002/smll.201001257.

[18] Mahmoudi, M., Simchi, A., Imani, M., Milani, A. S., \& Stroeve, P. (2008). Optimal design and characterization of superparamagnetic iron oxide nanoparticles coated with polyvinyl alcohol for targeted delivery and imaging. Journal of Physical Chemistry B, 112(46), 14470-14481. doi:10.1021/jp803016n.

[19] Morris, R. V., Lauer, H. V., Lawson, C. A., Gibson, E. K., Nace, G. A., \& Stewart, C. (1985). Spectral and other physicochemical properties of submicron powders of hematite (alpha -Fe2O3), maghemite (gamma - Fe2O3), magnetite (Fe3O4), goethite (alpha - $\mathrm{FeOOH}$ ) and lepidocrocite (gamma -FeOOH). Journal of Geophysical Research, 90(B4), 3126-3144. doi:10.1029/JB090iB04p03126.

[20] Long, N. V., Yang, Y., Teranishi, T., Thi, C. M., Cao, Y., \& Nogami, M. (2015). Related magnetic properties of CoFe2O4 cobalt ferrite particles synthesised by the polyol method with $\mathrm{NaBH} 4$ and heat treatment: new micro and nanoscale structures. RSC Advances, 5(70), 56560-56569. doi:10.1039/c5ra10015a.

[21] Francis, A. J., \& Dodge, C. J. (1988). Anaerobic Microbial Dissolution of Transition and Heavy Metal Oxides. Applied and Environmental Microbiology, 54(4), 1009-1014. doi:10.1128/aem.54.4.1009-1014.1988.

[22] Shohet, J. L. (1991). Plasma-Aided Manufacturing. IEEE Transactions on Plasma Science, 19(5), 725-733. doi:10.1109/27.108405.

[23] Ostrikov, K. (2005). Reactive plasmas as a versatile nanofabrication tool. Reviews of Modern Physics, 77(2), 489-511. doi:10.1103/RevModPhys.77.489. 
[24] Lee, E. T., Jang, G. E., Kim, C. K., \& Yoon, D. H. (2001). Fabrication and gas sensing properties of $\alpha$-Fe2O3 thin film prepared by plasma enhanced chemical vapor deposition (PECVD). Sensors and Actuators, B: Chemical, 77(1-2), $221-227$. doi:10.1016/S0925-4005(01)00716-X.

[25] Lian, J., Duan, X., Ma, J., Peng, P., Kim, T., \& Zheng, W. (2009). Hematite ( $\alpha$-Fe2O3) with various morphologies: Ionic liquidassisted synthesis, formation mechanism, and properties. ACS Nano, 3(11), 3749-3761. doi:10.1021/nn900941e.

[26] Tadic, M., Panjan, M., Damnjanovic, V., \& Milosevic, I. (2014). Magnetic properties of hematite $\left(\alpha-\mathrm{Fe}_{2} \mathrm{O}_{3}\right)$ nanoparticles prepared by hydrothermal synthesis method. Applied Surface Science, 320(30), 183-187. doi:10.1016/j.apsusc.2014.08.193.

[27] Lee, D., Choi, Y. W., Na, Y. S., Choi, S. S., Park, D. W., \& Choi, J. (2015). Fe2O3 nanopowders prepared by a thermal plasma process for water oxidation. Materials Research Bulletin, 68, 221-226. doi:10.1016/j.materresbull.2015.03.045.

[28] Asoufi, H. M., Al-Antary, T. M., \& Awwad, A. M. (2018). Green route for synthesis hematite ( $\alpha$-Fe2O3) nanoparticles: Toxicity effect on the green peach aphid, Myzus persicae (Sulzer). Environmental Nanotechnology, Monitoring and Management, 9, 107-111. doi:10.1016/j.enmm.2018.01.004.

[29] Pech, J., Hannoyer, B., \& Marest, G. (2000). Duplex structure of oxides produced on low-carbon steel surfaces after DC plasma jet treatment. Surface and Coatings Technology, 124(2-3), 228-234. doi:10.1016/S0257-8972(99)00628-3.

[30] Drickamer, H. G., Lynch, R. W., Clendenen, R. L., \& Perez-Albueene, E. A. (1967). X-Ray Diffraction Studies of the Lattice Parameters of Solids under Very High Pressure. Solid State Physics - Advances in Research and Applications, 19(C), $135-228$. doi:10.1016/S0081-1947(08)60529-9.

[31] Zhu, L. P., Bing, N. C., Wang, L. L., Jin, H. Y., Liao, G. H., \& Wang, L. J. (2012). Self-assembled 3D porous flowerlike $\alpha$-Fe $2 \mathrm{O} 3$ hierarchical nanostructures: Synthesis, growth mechanism, and their application in photocatalysis. Dalton Transactions, 41(10), 2959-2965. doi:10.1039/c2dt11822j.

[32] Kouotou, P. M., Tian, Z. Y., Vieker, H., Beyer, A., Gölzhäuser, A., \& Kohse-Höinghaus, K. (2013). Selective synthesis of $\alpha$ $\mathrm{Fe} 2 \mathrm{O} 3$ thin films and effect of the deposition temperature and lattice oxygen on the catalytic combustion of propene. Journal of Materials Chemistry A, 1(35), 10495-10504. doi:10.1039/c3ta11354j.

[33] Lee, S., \& Park, J. W. (2020). Hematite/graphitic carbon nitride nanofilm for fenton and photocatalytic oxidation of methylene blue. Sustainability (Switzerland), 12(7), 1-15. doi:10.3390/su12072866.

[34] Hussain, S. A., Radi, A. J., Najim, F. A., \& Shaheed, M. A. (2020). Structural, Optical and Sensing Properties of ZnO:Cu Films Prepared by Pulsed Laser Deposition. Journal of Physics: Conference Series, 1591(1), 012088. doi:10.1088/17426596/1591/1/012088.

[35] Navale, S. T., Mali, V. V., Pawar, S. A., Mane, R. S., Naushad, M., Stadler, F. J., \& Patil, V. B. (2015). Electrochemical supercapacitor development based on electrodeposited nickel oxide film. RSC Advances, 5(64), 51961-51965. doi:10.1039/c5ra07953e.

[36] Tarwal, N. L., \& Patil, P. S. (2010). Superhydrophobic and transparent ZnO thin films synthesized by spray pyrolysis technique. Applied Surface Science, 256(24), 7451-7456. doi:10.1016/j.apsusc.2010.05.089.

[37] Wenzel, R. N. (1936). Resistance of solid surfaces to wetting by water. Industrial and Engineering Chemistry, 28(8), 988-994. doi:10.1021/ie50320a024.

[38] Cassie, A. B. D., \& Baxter, S. (1944). Wettability of porous surfaces. Transactions of the Faraday Society, 40, 546-551. doi:10.1039/tf9444000546.

[39] Wang, Z., Lee, Y. H., Wu, B., Horst, A., Kang, Y., Tang, Y. J., \& Chen, D. R. (2010). Anti-microbial activities of aerosolized transition metal oxide nanoparticles. Chemosphere, 80(5), 525-529. doi:10.1016/j.chemosphere.2010.04.047.

[40] Sun, H. qi, Lu, X. mei, \& Gao, P. ji. (2011). The exploration of the antibacterial mechanism of Fe3+ against bacteria. Brazilian Journal of Microbiology, 42(1), 410-414. doi:10.1590/S1517-83822011000100050.

[41] Weltmann, K. D., Kinde, E., Von Woedtke, T., Hähnel, M., Stieber, M., \& Brandenburg, R. (2010). Atmospheric-pressure plasma sources: Prospective tools for plasma medicine. Pure and Applied Chemistry, 82(6), 1223-1237. doi:10.1351/PACCON-09-10-35.

[42] Shintani, H., Sakudo, A., Burke, P., \& McDonnell, G. (2010). Gas plasma sterilization of microorganisms and mechanisms of action. Experimental and Therapeutic Medicine, 1(5), 731-738. doi:10.3892/etm.2010.136.

[43] Ferreira, S. D., Dernell, W. S., Powers, B. E., Schochet, R. A., Kuntz, C. A., Withrow, S. J., \& Wilkins, R. M. (2001). Effect of gas-plasma sterilization on the osteoinductive capacity of demineralized bone matrix. Clinical Orthopaedics and Related Research, 388(388), 233-239. doi:10.1097/00003086-200107000-00032.

[44] Shintani, H., Shimizu, N., Imanishi, Y., Sekiya, T., Tamazawa, K., Taniguchi, A., \& Kido, N. (2007). Inactivation of microorganisms and endotoxins by low temperature nitrogen gas plasma exposure. Biocontrol Science, 12(4), $131-143$. doi:10.4265/bio.12.131. 
[45] Weltmann, K. D., \& Von Woedtke, T. (2017). Plasma medicine - Current state of research and medical application. Plasma Physics and Controlled Fusion, 59(1), 014031-01438. doi:10.1088/0741-3335/59/1/014031.

[46] Tanaka, H., Mizuno, M., Ishikawa, K., Toyokuni, S., Kajiyama, H., Kikkawa, F., \& Hori, M. (2018). Molecular mechanisms of non-thermal plasmainduced effects in cancer cells. Biological Chemistry, 400(1), 87-91. doi:10.1515/hsz-2018-0199.

[47] Shen, J., Tian, Y., Li, Y., Ma, R., Zhang, Q., Zhang, J., \& Fang, J. (2016). Bactericidal Effects against S. aureus and Physicochemical Properties of Plasma Activated Water stored at different temperatures. Scientific Reports, 6(1), 28505-28509. doi:10.1038/srep28505.

[48] Kamgang-Youbi, G., Herry, J. M., Meylheuc, T., Brisset, J. L., Bellon-Fontaine, M. N., Doubla, A., \& Naïtali, M. (2009). Microbial inactivation using plasma-activated water obtained by gliding electric discharges. Letters in Applied Microbiology, 48(1), 13-18. doi:10.1111/j.1472-765X.2008.02476.x.

[49] Lee, K., Paek, K., Ju, W. T., \& Lee, Y. A Study on the Effect of Microbial Sterilization Using Plasma Generator with a Flexible Electrodes Structure. Journal of the Korean Institute of Electrical and Electronic Material Engineers, 33(1), 70-77. doi:10.4313/JKEM.2020.33.1.70.

[50] Nicol, M. K. J., Brubaker, T. R., Honish, B. J., Simmons, A. N., Kazemi, A., Geissel, M. A., Whalen, C. T., Siedlecki, C. A., Bilén, S. G., Knecht, S. D., \& Kirimanjeswara, G. S. (2020). Antibacterial effects of low-temperature plasma generated by atmospheric-pressure plasma jet are mediated by reactive oxygen species. Scientific Reports, 10(1), 59652-6. doi:10.1038/s41598-020-59652-6.

[51] Bălan, G. G., Roşca, I., Ursu, E. L., Doroftei, F., Bostănaru, A. C., Hnatiuc, E., Năstasă, V., Şandru, V., Ştefănescu, G., Trifan, A., \& Mareş, M. (2018). Plasma-activated water: A new and effective alternative for duodenoscope reprocessing. Infection and Drug Resistance, 11, 727-733. doi:10.2147/IDR.S159243.

[52] Martusevich, A. K., Solov'eva, A. G., Galka, A. G., Kozlova, L. A., \& Yanin, D. V. (2019). Effects of Helium Cold Plasma on Erythrocyte Metabolism. Bulletin of Experimental Biology and Medicine, 167(2), 198-200. doi:10.1007/s10517-019-04490-4.

[53] Lu, H., Patil, S., Keener, K. M., Cullen, P. J., \& Bourke, P. (2014). Bacterial inactivation by high-voltage atmospheric cold plasma: Influence of process parameters and effects on cell leakage and DNA. Journal of Applied Microbiology, 116(4), 784794. doi:10.1111/jam.12426.

[54] Shin, N., Saravanakumar, K., \& Wang, M.-H. (2019). Sonochemical Mediated Synthesis of Iron Oxide (Fe3O4 and Fe2O3) Nanoparticles and their Characterization, Cytotoxicity and Antibacterial Properties. Journal of Cluster Science, 30(3), 669-675. doi:10.1007/s10876-019-01526-7

[55] Belkhedkar, M. R., Ubale, A. U., Sakhare, Y. S., Zubair, N., \& Musaddique, M. (2016). Characterization and antibacterial activity of nanocrystalline $\mathrm{Mn}$ doped $\mathrm{Fe} 2 \mathrm{O} 3$ thin films grown by successive ionic layer adsorption and reaction method. Journal of the Association of Arab Universities for Basic and Applied Sciences, 21, 38-44. doi:10.1016/j.jaubas.2015.03.001. 